\title{
PT Telkom's Competitive Strategy in the Digital Industry in Indonesia
}

\author{
Willy Abdilah ${ }^{1}$, Berto Usman $^{2}$, Eryk Lesmono $^{3}$ \\ Faculty of Economics and Business - Bengkulu University ${ }^{1,2,3}$ \\ \{willy.abdilah@gmail.com \}
}

\begin{abstract}
The trend of revenue declining in the global telecommunications industry in recent years, has also being experienced by PT Telkom Indonesia. This situation requires PT Telkom to find other revenue engines through digital business. However, the performance of its digital business has not contributed significantly to the company's revenue. The purpose of this research is to identify the factors why PT Telkom's Digital Business Unit, particularly in consumer digital, is not able to compete in the digital industry in Indonesia as well as crafting the right business strategy to be implemented by PT Telkom's Digital Business Unit in order to win the competition in the digital industry in Indonesia. Through qualitative research with a descriptive approach, data collection is done through in-depth documentation and interview technique.
\end{abstract}

Keywords: Digital Business; Competitive Advantage; Improvement Strategy Competitive Advantage; Digital Telecommunication

\section{Introduction}

A research conducted by Frost and Sullivan Indonesia [1] stated that the revenue opportunity in the digital industry in Indonesia is predicted to reach a value of $\$ 9.5$ billion by 2022 , with the largest contribution coming from five digital consumer businesses, which are e-commerce, digital advertising, digital wallet services, pay TV and gaming. These prediction numbers have attracted some global players to come to enliven the digital business in Indonesia. This situation is not only an opportunity because of the high demand for digital services, but also a threat because of the many world-class companies involved in the digital industry in Indonesia.

The trends of telecommunications business that continue to decline and digital business that continues to grow encourage PT Telkom to transform its business by not only focusing on the voice and SMS legacy business, but also trying to create new revenue engines through digital business. PT Telkom creates a business unit that focuses on developing digital consumer businesses, called Customer Facing Unit Digital Business. This business unit is in charge of several Telkom digital products, such as Blanja.com and Langit Musik.

The contribution of PT Telkom's digital portfolio business unit to the company's consolidated revenue in 2018 was around 11\%, with total revenue of IDR 1,039 Trillion and negative EBIT (-) IDR 60 billion. Whereas, the potential for digital business in Indonesia in that year was predicted as much as \$ 2.9 billion (Frost and Sullivan Indonesia, 2018); This shows that PT Telkom's digital business is not fully able to compete with other digital companies yet. 
Based on the above explanations, there is a gap between the performance of PT Telkom's digital business units and the digital industry in Indonesia. This encourages the researcher to study further about the reasons for the performance of PT Telkom's digital business units in which have not been able to compete and will also be given the proper business strategy to be implemented in PT Telkom's digital business units in order to compete in the digital business industry in Indonesia.

\section{Theoretical Framework}

Thompson, et.al. [2] stated that in developing strategies which are suitable to the company's situation, an in-depth diagnosis of the external and internal environment is required. Strategic thinking starts with evaluating the company's external and internal environment (as a basis for deciding long-term direction and developing a strategic vision), then moves towards evaluating alternative strategies and the most promising business models for the company, and leads to the selection of certain strategies.

Managers need to conduct a multilevel analysis and make an effort to understand various pressures in operating at each level of the system to understand the world around the company. There are three levels of analysis of the external environment according to Galavan [3];

a. Macro environment analysis is conducted to identify strengths in the business environment which tend to have a significant influence on the industry. Tool that can be used is PESTLE analysis.

b. Industry analysis is carried out to identify sources of competition that will affect to profitability. Porter's five forces analysis is used to analyze the current situation in the certain industry.

c. Organizational Analysis is carried out to identify the impact of the macro and industrial environment to the company. The results of the analysis must take the form of opportunities or threats, and are explained in the form of key success factors of the company.

SWOT analysis is a simple and powerful tool to measure strengths, weaknesses, opportunities and threats of the company. The SWOT matrix helps managers to develop four types of strategies: SO (strengths - opportunities), WO (weaknesses - opportunities), ST (strengths - threats), WT (weaknesses - threats). The generic strategies proposed by Porter (1980) were later extended by Thompson, et, al. [2] is as follows:

a. A low-cost provider strategy - which seeks to achieve lower overall costs than competitors on comparable products that attract a broad spectrum of buyers, usually at a lower price compare to the competitor's price.

b. A broad differentiation strategy_-seeking to differentiate the company's product offering from rivals' with attributes that will appeal to a broad spectrum of buyers.

c. A focused low-cost strategy - concentrating on the needs and requirements of niche market and striving to meet these needs at lower costs than rivals.

d. A focused differentiation strategy-concentrating on a narrow buyer segment and outcompeting rivals by offering niche members customized attributes that meet their tastes and requirements better than rivals' products.

e. A best-cost provider strategy-striving to incorporate upscale product attributes at a lower cost than rivals.

The study related to this research is a study conducted by Kurniawan [4] which identified the positioning of the Telkom Group in the telecommunications industry in Indonesia using BCG matrix. The results showed that at that time Telkom Group was included in the star 
quadrant because of the high market share and growth in customers. One of the recommended strategies to maintain competitive advantage which was already owned and to gain new market share is to make continuous innovation in the unified communication industry, including digital business which includes communication from basic services to advance services, open platforms, integrated business application and cloud computing.

Another study was conducted by Danso [5] which aims to identify the strategies adopted by cellular telecommunications operators to gain a competitive benefit in the telecommunications industry in Ghana. The results found that the provision of a customer service center, ongoing advertising campaigns, staff training to improve competence and skills are competitive strategies that are being implemented by cellular telecommunications operators. Operators must continue to monitor and evaluate their competitive advantages by first identifying specific changes in the market such as if the company's products have low demand, then it is time to vary the product according to customer needs and satisfaction. Operators must remain competitive in the telecommunications market by continuously redefining and reinventing corporate strategy.

\section{Methodology}

The research design used in this study was a case study. This research used a descriptive qualitative research, which is a research that emphasizes the understanding of problems based on holistic complex and detailed reality [6]. The data collection method in this study used the following methods:

a. In depth interview and questionnaire. The primary data in this research is collected by using in-depth interview and questionnaire. The selected informants are senior leader in PT Telkom's digital business unit, so the validity of the data obtained can be accounted.

b. Documentation. Secondary data in this study were conducted by collecting and analyzing documents, both written documents, images and electronics [7].

Data analysis of this study was a descriptive method. Descriptive analysis is a form of research that aims to provide a systematic and accurate picture of the facts, nature and relationships between the phenomena studied by collecting, presenting and analyzing data which then draws conclusions from existing conditions in the organization under study.

\section{Results and Discussion}

External and internal analysis were required to detect and identify conditions that affect the competitive advantage of PT Telkom's Digital Business Unit. Internal environment is the situation that can be conditioned by PT Telkom's Digital Business Unit. Internal analysis of the competitive advantage of PT Telkom's Digital Business Unit was carried out using VRIO analysis. VRIO analysis is an internal analysis that examines the resources and capabilities of PT Telkom's Digital Business Unit. The results of the VRIO analysis are as follows: 
Table 1. VRIO Analysis of Digital Business Unit of PT Telkom

\begin{tabular}{|c|c|c|c|c|c|c|}
\hline No & Findings & $v$ & $\boldsymbol{R}$ & $I$ & $O$ & Conclusion \\
\hline 1 & $\begin{array}{l}\text { The availability of infrastructure assets, connectivity } \\
\text { and coverage of Telkom is very adequate. }\end{array}$ & $\mathrm{v}$ & $\mathrm{v}$ & $\mathrm{x}$ & $\mathrm{v}$ & $\begin{array}{l}\text { Is a typical strength and } \\
\text { competency that is } \\
\text { sustainable }\end{array}$ \\
\hline 2 & $\begin{array}{l}\text { The ability to move towards digital business } \\
\text { through the acquisition of subsidiaries, the Indigo } \\
\text { program and internal incubation of human capital. }\end{array}$ & $\mathrm{v}$ & $\mathrm{v}$ & $\mathrm{v}$ & - & $\begin{array}{l}\text { Is a typical strength and } \\
\text { competency that is not } \\
\text { sustainable }\end{array}$ \\
\hline 3 & $\begin{array}{l}\text { Less aggressive in digital business as a publicly } \\
\text { owned company. }\end{array}$ & $\mathbf{x}$ & - & - & $x$ & Is a weakness \\
\hline${ }^{4}$ & $\begin{array}{l}\text { Having a variety of digital products that can not bo } \\
\text { sold well. }\end{array}$ & $\mathbf{x}$ & - & - & $x$ & Is a weakness \\
\hline 5 & $\begin{array}{l}\text { Having a digital business platform that supports } \\
\text { digital sales and marketing. }\end{array}$ & $\mathrm{v}$ & v & $\mathrm{v}$ & - & $\begin{array}{l}\text { Is a typical strength and } \\
\text { competency that is not } \\
\text { sustainable }\end{array}$ \\
\hline 6 & $\begin{array}{l}\text { Slow adoption of technology is judged because the } \\
\text { decision making for tochnology implementation } \\
\text { with a long process. }\end{array}$ & $\mathbf{x}$ & - & - & $\mathrm{x}$ & Is a weakness \\
\hline 7 & \begin{tabular}{|l} 
Telkom's research and development is more \\
technological exploration to provide study \\
recommendations, before researching specific \\
coustomer needs.
\end{tabular} & $\mathrm{x}$ & - & $\mathrm{x}$ & - & Is a weakness \\
\hline 8 & $\begin{array}{l}\text { Still need to develop platforms in a more appropriate } \\
\text { way so that the focus enters the digital business. }\end{array}$ & $\mathbf{x}$ & - & $\mathrm{x}$ & - & Is a weakness \\
\hline 9 & $\begin{array}{l}\text { Limited quality of human resources that can develop } \\
\text { Telkom's digital business }\end{array}$ & $\mathbf{x}$ & - & $\mathbf{x}$ & - & Is a weakness \\
\hline 10 & $\begin{array}{l}\text { Development of digital capabilities and mindset in } \\
\text { all Telkom work units through the Amoeba } \\
\text { program. }\end{array}$ & $\mathrm{v}$ & $\mathrm{v}$ & $\mathrm{x}$ & $\mathrm{v}$ & $\begin{array}{l}\text { Is a typical strength and } \\
\text { competency that is } \\
\text { sustainable }\end{array}$ \\
\hline 11 & $\begin{array}{l}\text { The reputation of providing Telkom services is } \\
\text { trusted because of the availability of network } \\
\text { infrastructure and employees spread throughout } \\
\text { Indonesia. }\end{array}$ & $\mathrm{v}$ & $\mathrm{v}$ & $\mathrm{x}$ & $\mathrm{v}$ & $\begin{array}{l}\text { Is a typical strength and } \\
\text { competency that is } \\
\text { sustainable }\end{array}$ \\
\hline 12 & $\begin{array}{l}\text { Have not found the right digital business model to } \\
\text { be able to create optimal revenue and profit. }\end{array}$ & $\mathrm{x}$ & - & $\mathrm{x}$ & - & Is a weakness \\
\hline
\end{tabular}

PESTLE analysis and Porter's five forces analysis are used to examine the external environment in this research. The result of the analysis are can be explained as follows: a. PESTLE Analysis the PESTLE condition is a condition that can determine a company's growth including the company's competitive advantage. This PESTLE condition was directed in relation to the competitive advantage of PT Telkom's Digital Business Unit. The results of the PESTLE analysis can be seen in the following table 2.

Table 2. PESTLE Conditions That Determine the Competitive Advantage of PT Telkom's Digital Business Unit

\begin{tabular}{|c|c|c|c|c|}
\hline V & \multirow{2}{*}{ Envirsoment Fadden } & \multirow{2}{*}{ Findiags } & \multicolumn{2}{|c|}{ Implications } \\
\hline $\mathrm{Na}$ & & & Indatry & Company \\
\hline \multirow{2}{*}{ 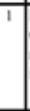 } & \multirow{2}{*}{ 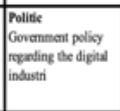 } & 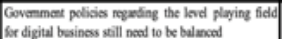 & 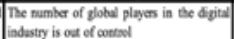 & 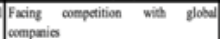 \\
\hline & & 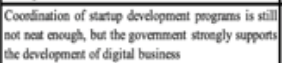 & 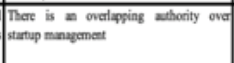 & 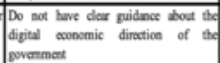 \\
\hline \multirow[t]{3}{*}{2} & \multirow[t]{3}{*}{ 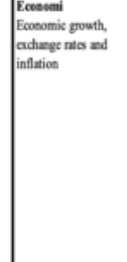 } & 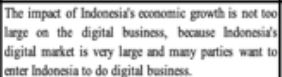 & 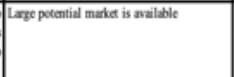 & 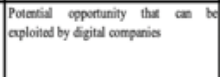 \\
\hline & & 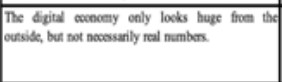 & \begin{tabular}{|l|} 
Compecibion oxur in tems of ompany \\
valuations
\end{tabular} & 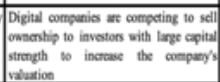 \\
\hline & & 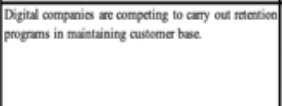 & 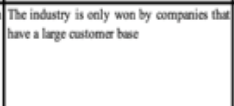 & 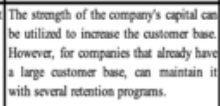 \\
\hline \multirow[t]{2}{*}{3} & \multirow[t]{2}{*}{$\begin{array}{l}\text { Sodial } \\
\text { Lifstyle, aulture }\end{array}$} & 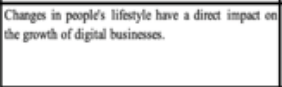 & 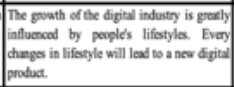 & 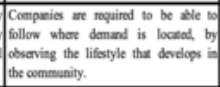 \\
\hline & & 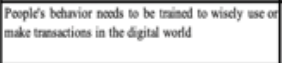 & 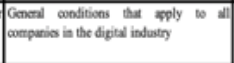 & 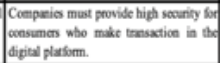 \\
\hline \multirow[t]{2}{*}{4} & \multirow[t]{2}{*}{ 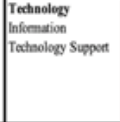 } & 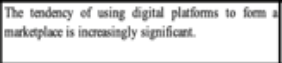 & 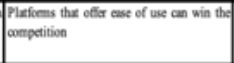 & 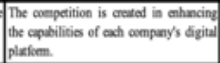 \\
\hline & & 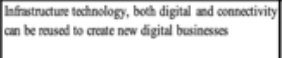 & 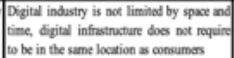 & 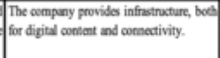 \\
\hline 5 & \begin{tabular}{|l|} 
Leqal \\
Requalations mitived to \\
digitul business
\end{tabular} & There are no spostific nula goveming digital basiness & 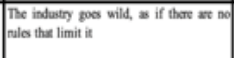 & 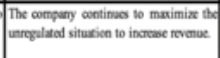 \\
\hline
\end{tabular}


The findings on the situation of the digital industry in Indonesia that affect to PT Telkom's digital business can be seen in the following table 3 .

Table 3. Industrial Strength Conditions that Determine Competitive Advantage of PT Telkom's Digital Business Unit

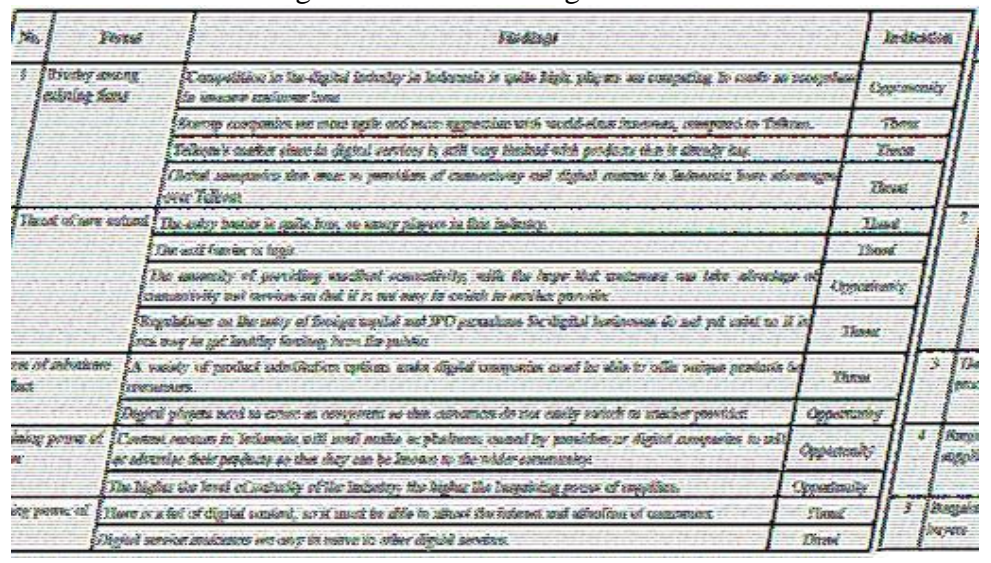

The results of the questionnaire against the respondents obtained that the intensity of competition in the digital industry in Indonesia are as follows:

Table 4. Intensity of Digital Industry Competition in Indonesia

\begin{tabular}{|c|c|c|c|c|}
\hline Forces & Indicators & $\begin{array}{l}\text { Average } \\
\text { Result }\end{array}$ & Mid Value & Result \\
\hline \multirow{4}{*}{$\begin{array}{c}\text { Bargaining } \\
\text { Power of } \\
\text { Buyers }\end{array}$} & Price sensitivity & \multirow{4}{*}{4,63} & \multirow{4}{*}{3,75} & \multirow{4}{*}{ Strength } \\
\hline & Switching cost & & & \\
\hline & Numbers of player & & & \\
\hline & Information ownership & & & \\
\hline \multirow{4}{*}{$\begin{array}{c}\text { Bargaining } \\
\text { Power Of } \\
\text { Supplier }\end{array}$} & Numbers of supplier & \multirow{4}{*}{2,75} & \multirow{4}{*}{3,75} & \multirow{4}{*}{ Weak } \\
\hline & Company's ability to produce & & & \\
\hline & Switching cost & & & \\
\hline & Labor availability & & & \\
\hline \multirow{3}{*}{$\begin{array}{c}\text { Threat Of } \\
\text { Subtitute } \\
\text { Product }\end{array}$} & Numbers of substitute product & \multirow{3}{*}{3,89} & \multirow{3}{*}{3,75} & \multirow{3}{*}{ Moderate } \\
\hline & Quality of substitute product & & & \\
\hline & Switching cost & & & \\
\hline \multirow{3}{*}{$\begin{array}{c}\text { Threat Of } \\
\text { New } \\
\text { Entrant }\end{array}$} & Capital requirement & \multirow{3}{*}{4,06} & \multirow{3}{*}{3,75} & \multirow{3}{*}{ Strength } \\
\hline & Customer loyalty & & & \\
\hline & Convenience for other companies & & & \\
\hline \multirow{4}{*}{$\begin{array}{c}\text { Rivalry } \\
\text { Among } \\
\text { Existing } \\
\text { Firm }\end{array}$} & Differentiation in Industry & \multirow{4}{*}{4,46} & \multirow{4}{*}{3,75} & \multirow{4}{*}{ Strength } \\
\hline & Numbers of player & & & \\
\hline & Business growth & & & \\
\hline & Company's strength in industry & & & \\
\hline
\end{tabular}

Based on the analysis conducted in the previous discussion, the researcher identified key success factors that must be owned by PT Telkom's Digital Business Unit in order to be able to compete in the digital industry in Indonesia including being innovative in developing digital products, having platforms and digital ecosystems, being aggressive in promoting and HR who have digital skills and capabilities.

The suitable strategy to be carried out by PT Telkom's Digital Business Unit in order to be able to compete in the digital industry in Indonesia is a strategy to increase competitive advantage obtained by analyzing external and internal factors of PT Telkom's Digital Business Unit. The total EFAS score obtained was 2.64. This showed that the strategy implemented by 
the company has been designed well enough to meet the opportunities and survive the threats. The opportunity aspect that had the highest points was a change in people's lifestyle with a score of 0.15 , while the threat factor came from more agile startup companies and digital business rules that had not existed, each of which had a score of 0.12 .

The total IFAS score obtained was 2.75 . This indicates that the company was weak against its competitors. The strength factor of the company that had the highest points is the customer base Telkom Group which amounted to around 250 million with a score of 0.10 , while some of the company's main weaknesses were less aggressive, inadequate skills and do not yet have the right business model for digital businesses, each of which has a score 0.12 .

IE (Internal - External) matrix was conducted by combining the IFAS score and EFAS score that had been discussed previously, so that the coordinates is $(2.64 ; 2.75)$. The following IE Matrix shows that the company's position is in cell $\mathrm{V}$, which is recommended to implement hold and maintain strategy. The real action to be done is focus on market penetration and product development.

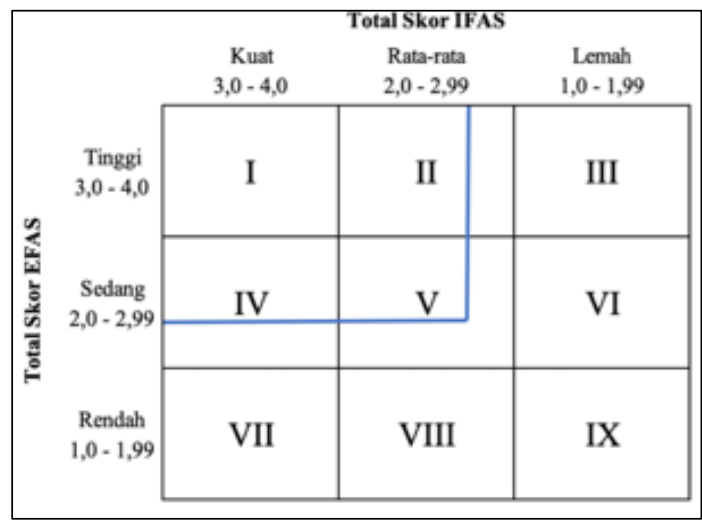

Fig. 1. IE (Internal - External) Matrix

The suitable business strategies to increase the competitive advantage of PT Telkom's Digital Business Unit as the result of the SWOT analysis included:

a. Optimizing Telkom's infrastructure assets and coverage with a focus on developing digital businesses in accordance with market demand.

b. Optimizing customer-based Telkom Group to offer digital services, especially to customers who have not been touched by Telkom's digital products.

c. Intensifying and extending the digital business platform.

d. Developing digital services that provide satisfaction and match customer needs.

e. Making innovations on digital services products by optimizing the use of available connectivity.

f. Maximizing synergy between business units and entities within Telkom Group.

g. Periodically evaluate the quality of digital services to produce customer satisfaction and loyalty towards Telkom digital services.

h. Performing adjustments to digital services and product services that are in line with changes in the external environment for consumers.

i. Producing and marketing digital services with many variations that are easily accessed by customers. 
j. Establish the suitable business model for digital services in response to high demand due to changes in people's lifestyle.

k. Maximizing the R\&D function in creating digital products that customers need.

1. Developing organizational capabilities that support digital business.

m. Accelerating the adoption of digital technology to produce competitive digital service provision for consumers.

n. Increased skills and knowledge about digital business through alliances with global players or local startup companies.

o. Changing the approach to marketing and business development. For example forming a digital roadmap together with industry players.

p. Divesting digital services that have a tendency to lose money.

In the previous discussion it was found that the Telkom Group has a customer base of up to 250 million customers. Some of the products offered in the digital consumer segment have also not been able to attract customers to use these products, so Telkom's market share in digital services is still very limited. Based on these findings, the right generic competitive strategy for PT Telkom's Digital Business Unit to be able to increase its competitive advantage is a focused differentiation strategy. The focus strategy is intended to maximize the Telkom Group's customer base in offering its digital products, while the differentiation strategy is carried out by studying the customer's needs and behavior to produce digital products that have more value than other digital products.

\section{Conclusions}

Our study found some results that can be summarized as follow. First, external factors which are the reason for PT Telkom's Digital Business Unit has not been able to compete include: (1) consumers of digital services which are easy to move to other digital services as a result of the large amount of digital content provided by other services so that digital companies must be able to attract consumer interest and attention with something different, (2) start-up companies are more agile and aggressive with world-class investors, compared to Telkom which is more rigid due to state-owned status, (3) world-class digital companies have built digital ecosystems before entering Indonesia, so that Telkom lags behind several competitors because Telkom does not yet fully have a digital product ecosystem that can encourage customer-based enhancement, (4) Telkom has not been able to utilize the connectivity it has to provide digital services which results in the lack of digital services use service and platform owned by Telkom and Telkom's portion of digital services is still very limited.

While the internal factors that are the reason for PT Telkom's Digital Business Unit have not been able to compete include: (1) there have not been finding yet the right digital business model to be able to create optimal revenue and profit, (2) less aggressive in digital business as a stateowned public company, (3) limited quality of human resources that can develop Telkom's digital business, (4) slow in adopting digital technology because of the decision making for technology implementation with process the long term, (5) still needs to develop a platform in a more appropriate way so that the focus enters the digital business, (6) has a variety of digital products that cannot be sold well, (7) Telkom's research and development is more exploratory in technology to provide recommendations for studies, haven't researched specific customer needs.

Second, the appropriate generic competitive strategy to be implemented by PT Telkom's Digital Business Unit is the focus differentiation strategy. However, this study have some 
limitations encountered, such as there is no access to Director of Digital Business, thus allowing data or information obtained in this study to be less comprehensive. This research also focuses on the digital consumer business, while there are still enterprise and wholesale digital segments that have not been studied. Therefore, it is important for future studies to conduct periodic and continuous evaluations of the strategy to increase competitive advantage of PT Telkom's Digital Business Unit. Also, mapping the potential market for digital services to create a more competitive advantage over PT Telkom's Digital Business Unit, examining digital business in the enterprise segment to represent the company's overall digital group performance, and identifies the right business model for PT Telkom's digital business unit to be able to compete in the digital industry in Indonesia.

\section{References}

[1] Frost \& Sullivan. 2018. Digital Market Overview: Indonesia.

[2] Thompson, Arthur A., Peteraf, M.A., Gamble, J.E., Strickland, A.J. 2018. Crafting \& Executing Strategy: The Quest for Competitive Advantage, Concepts And Cases. New York: McGraw- Hill Education.

[3] Galavan, Robert. 2004. Doing Business Strategy. Ireland: NuBooks.

[4] Kurniawan, Mimin Deca. 2013. Strategi Bersaing Telkom Group Dalam Industri Telekomunikasi. Tesis Magister Managemen Universitas Gajah Mada.

[5] Danso, S.A. 2014. Adopting Competitive Strategies in the Telecommunications Industry. Journal of Information Engineering and Application. Vol. 4, No.11.

[6] Supomo, B. dan Indriantoro, N. 2009. Metodologi Penelitian Bisnis untuk Akuntansi dan Manajemen. Edisi Pertama. Yogyakarta: BPFE.

[7] Moleong, L.J. 2007. Metodologi Penelitian Kualitatif. Bandung: Penerbit PT Remaja Rosdakarya

[8] https: //ww2.frost.com/files/3115/2878/4354/Digital_Market_Overview_FCO_ Indonesia_2 18.pdf diakses 10 September 2019.

[9] Barney, Jay. 2014. Gaining and Sustaining Competitive Advantage $4^{\text {th }}$ Edition. United Kingdom: Pearson Education Limited.

[10] Dadhe, Archana. 2016. Strategic Management $2^{\text {nd }}$ Edition. India: Department of Management Sciences \& Research, G.S. College of Commerce \& Economics.

[11] Wheelen TL., Hunger JD. 2012. Strategic Management and Business Policy: Toward Global Sustainability. 13 ${ }^{\text {th }}$ edition. United States of America: Pearson Education Inc.

[12] Porter, Michael E. 1998. Competitive Strategy: Techniques for Analyzing Industries and Competitors. Brookline: The Free Pass. 